\title{
TRANSFORMATION OF SINGLE-FAMILY RESIDENTIAL ZONE OF LVIV (THE CASE OF KOZELNYKY NEIGHBORHOOD)
}

\author{
Iryna HUDZELIAK \\ Ivan Franko National University of Lviv, Ukraine \\ iryna.hudzelyak@Inu.edu.ua
}

\begin{abstract}
The single-family residential zone occupies an important place in the geospatial organization of the city of Lviv. According to the genesis, there are three types of single-family residential zone - former villages, which entered the administrative boundaries of the city in the 20th century; specially planned neighborhoods of single-family residence for different social groups of the population; small plots of single-family residence in the central part of the city in areas with a significant difference in height.

The spatial transformation of Kozelnyky began in the 1860s with the construction of the railway and led to the loss of part of the agricultural land and several residential neighborhoods. Joining Lviv in 1959 radically changed the geospatial organization of Kozelnyky. Industrial construction and the construction of city roads through the village contributed to the emergence of internal barriers, which, consequently, increased social isolation within the neighborhood. In present, Kozelnyky is a buffer between the southern industrial zone and the new Sykhiv residential district.

The neighborhood of Kozelnyky has stable borders, except for the south-eastern outskirts, where the construction of multi-storey buildings is the most intensive. Planning features of privatized land plots and narrow streets inhibit the penetration of urban architectural forms into rural construction. Construction compaction is mainly done by erecting annexes or new buildings on smallholdings without sharing them.

The population of Kozelnyky is about 1163 people, most of them are descendants of Ukrainians deported from Poland. The transformation of the social structure is mainly due to the change of generations with minimal migration. The specific social structure, hybrid features of everyday life and sustainable attitudes of most people to preserve the existing way of life will further slow down the spatial transformation and contribute to the preservation of the rural cultural landscape of the neighborhood.

The most acute problems of the neighborhood are: mostly dirt roads, lack of social facilities, in many households centralized water supply and sewerage. Solving these problems requires significant investments and purposeful urban planning decisions that will facilitate the integration of the single-family residential zone into the urban environment. The abandoned area with technical water settlers may in the future be turned into a recreational zone for the residents of Kozelnyky district and the adjacent multi-storey buildings.
\end{abstract}

Key words: single-family residential zone, city, urban space, transformation, Lviv, Kozelnyky.

DOI: https://doi.org/10.17721/2413-7154/2021.86.6-15

UDC: $911.375: 711.4(477.83-25)$

Received: June 08, 2021.

Revised: September 20, 2021.

Accepted: September 24, 2021.

ТРАНСФОРМАЦІЯ ЗОНИ САДИБНОЇ ЗАБУДОВИ МІСТА ЛЬВОВА (НА ПРИКЛАДІ МІКРОРАЙОНУ КОЗЕЛЬНИКИ) Ірина ГУДЗЕЛЯк

Львівський національний університет імені Івана Франка, Україна iryna.hudzelyak@Inu.edu.ua

Анотація: Зона садибної забудови посідає важливе місце у геопросторовій організації міста Львова. За генезисом виділено три типи садибної забудови - колишні села, які увійшли в адміністративну межу міста у XX ст.; спеціально сплановані квартали садибної забудови для різних соціальних груп населення; невеликі вкраплення садибної забудови у центральній частині міста на ділянках зі значним перепадом висот.

Просторова трансформація мікрорайону Козельники у Львові, який належить до першого типу, розпочалася у 1860-х рр. і призвела до втрати усіх сільськогосподарських земель та декількох житлових кварталів, появи внутрішніх бар'єрів, що у наслідку посилило соціальну ізоляцію усередині мікрорайону. На сучасному етапі Козельники $\epsilon$ буфером між промисловою зоною та новим житловим масивом Сихів. Зона садибної забудови має стійкі межі, за винятком південно-східної околиці, де найбільш інтенсивно ведеться будівництво багатоповерхівок. Планувальні особливості приватизованих земельних ділянок та вузькі вулиці гальмують проникнення міських архітектурних форм у сільську забудову. Ущільнення забудови в основному відбувається шляхом зведення прибудов чи нового житла на присадибних ділянках без їхнього подрібнення. Специфічна соціальна структура, гібридні риси повсякденного життя та стійкі установки більшості людей на збереження існуючого способу життя у подальшому сприятимуть збереженню переважно сільського культурного ландшафту мікрорайону.

Найбільш гострими проблемами у садибній забудові є: неякісні ґрунтові дороги, відсутність об'єктів соціальної сфери, у багатьох домогосподарствах централізованого водопостачання і водовідведення. Вирішення цих проблем потребує суттєвих капіталовкладень та цілеспрямованих містопланувальних рішень для покращення умов життя населення.

Ключові слова: зона садибної забудови, місто, міський простір, трансформація, Львів, Козельники. 
Актуальність дослідження. У структурі геопросторової організації житлової зони багатьох міст України важливе місце посідає садибна забудова. У великих містах України зона садибної забудови має незначну долю в структурі житлового фонду, але займає помітне місце у площі міста. Згідно Генерального плану міста Львова 2008 р. в садибній забудові було 708 тис. м² загальної площі житла, а це приблизно $5,5 \%$ житлового фонду міста (General development plan of Lviv ... 2008, p. 34). В результаті будівництва індустріальних об'єктів та багатоповерхового житла садибна забудова зазнала суттєвих трансформацій та набула цілого комплексу проблем, які слід вирішувати з урахуванням нових суспільних реалій.

Вітчизняні геоурбаністи практично не приділяли уваги питанням дослідження її розвитку i функціонування. Адже, в умовах надзвичайно динамічних змін урбаністичних ландшафтів, площа садибної забудови у великих містах в радянський час стрімко скорочувалася, на iï місці виростали нові райони багатоповерхової забудови. Поява інституту приватної власності в Україні у середині 1990-х років призупинила процес скорочення зони садибної забудови у великих містах. Власний будинок у місті оцінювався як солідний матеріальний статок родини, як основа майбутнього розширення житлових приміщень для нових поколінь. Внаслідок зупинки багатьох промислових підприємств у містах занедбані промислові зони почали розглядатися як зручні в інфраструктурному аспекті ділянки для житлового будівництва. Ревіталізація таких промислових зон уповільнила руйнування садибної забудови на деякий період. Проте, 3 кінця 2010-х років фрагменти старої садибної забудови, які збереглися у містах, знову розглядаються владою та компаніямизабудовниками переважно як перспективні ділянки для нового будівництва багатоповерхових житлових будинків і комерційної інфраструктури.

Однак, пандемія COVID-19 суттєво змінила головні цінності міських жителів, зокрема оцінку садиби як місця постійного проживання, адже мешкати в індивідуальному будинку виявилося більш комфортно, безпечно і привабливо. Цінові тренди на ринку нерухомості засвідчують повільне зростання цін на садибне житло. Тому в нових суспільних умовах варто посилити акценти у науковому дослідженні різних типів міського простору саме на зони садибної забудови, переглянути концептуальні підходи до планувальних рішень стосовно розвитку великих міст України, у тім числі Львова.

У старих європейських містах тривалі ринкові відносини уже давно перетворили райони садибної забудови в елітні високовартісні ділянки міського простору, які не лише не відрізняються, але й у багатьох випадках навіть перевершують середньоi багатоповерхову забудову за багатьма якісними параметрами інфраструктури та умов життя мешканців. В північноамериканських агломераціях величезні площі садибної забудови у передмістях функціонально злилися 3 міським ядром, що $\mathrm{e}$ успішним результатом цілеспрямованої політики містобудування та просторового розвитку. Однак, після фінансової кризи 2008 р. відбулася переоцінка житла середнім класом та особливо біднішими верствами населення. У тогочасних найбільш песимістичних прогнозах геоурбаністів садибна забудова поступово витіснятиметься більш дешевим невеликим житлом у багатоквартирних будинках малої і середньої поверховості нових міських ядер на околиці американських міст (Leinberger, 2008). Але тенденції на ринку житла у центральних кварталах великих міст США протягом літа-осені 2020 р. виявилися дещо іншими: суворий карантин спричинив відтік мешканців у передмістя. Невелике автономне житло 3 земельною ділянкою знову почало розглядатися середнім класом як найбільш привабливий варіант для сімей з дітьми, а квартири в багатоповерхівках у центрі міста поступово стають непопулярними.

Аналіз останніх публікацій. В розвинених країнах світу, попри наростаючу нуклеаризацію сімей, депопуляцію населення, появу на ринку житла нових генерацій людей 3 дещо іншими життєвими пріоритетами, нині зберігається достатньо висока орієнтація на життя в окремому будинку. Це відобразилося у сучасній тематиці урбаністичних досліджень. Окремий номер Journal of Urbanism присвячений розгляду різних аспектів функціонування садибної забудови. У підсумковій реферативній статті Марко Адельфіо узагальнив усі представлені дослідження, показав локальні особливості трансформації садибної забудови у різних країнах світу (Adelfio, 2014). Загалом науковці Європи та Північної Америки головно зосереджують увагу на питаннях пошуку можливостей та оптимальних моделей збалансованого й розумного розвитку різноманітного типу житлової забудови великих міст і субурбій.

В країнах, що розвиваються, динамічна урбанізація характеризується просторовим поглинанням старої сільської забудови індустріальною зоною та сучасними високоповерховими житловими районами. Ці тенденції дослідили Йінг Пан та Менгсі Тьян на прикладі китайського міста Гуанчжоу (Pan \& Tian, 2018). Автори зазначають, що явище «село в місті» (village-in-city) в сучасному китайському мегаполісі існує завдяки значному соціально-майновому розшаруванні в суспільстві. Робітники 3 найнижчими доходами обирають найдешевше житло в міських селах 3 низькоякісною дуже щільною забудовоюта відсутністю комунальної інфраструктури, часто практикуються примітивні прибудови для здачі в оренду. Саме існування «села в місті» забезпечує китайській індустрії достатню кількість дешевої робочої сили.

Група учених з декількох університетів США Могамед Бабікер Ібрагім, Лео Зулу, Фредерік Бейн - дослідила перехідний період трансформації села в мале місто в Західному Судані (Ibrahim et al., 2017). Автори наголошують на особливій моделі міського розвитку: не «зверху вниз», коли просторове розростання відбувається головно завдяки державним інвестиціям у міську (житлову та індустріальну) інфраструктуру, а «знизу вгору». Така модель $\epsilon$ 
органічною, адже залежить лише від фінансових ресурсів особистих селянських домогосподарств, які поступово модернізують житло та започатковують нові види економічної діяльності, пов'язані з наданням різноманітних «міських» послуг.

У вітчизняній геоурбаністиці питання трансформації зони садибної забудови великих міст глибоко не досліджувалося. У контексті взаємодії приміських просторів Києва і Вінниці 3 їх центральними районами авторський колектив географів Київського національного університету імені Тараса Шевченка у складі Костянтина Мезенцева, Наталії Провотар, Олексія Гнатюка, Анатолія Мельничука та Олени Денисенко виявив нові тенденції повсякденних практик населення, а також наслідки цього процесу - «радикальна зміна структури населення; втрата або гібридний характер місцевої ідентичності приміських поселень; випереджаючий розвиток житлової забудови за відставання розвитку відповідної інженерної та соціальної інфраструктури; наростаюча неоднорідність, фрагментарність та поліцентричність приміських просторів; посилення залежності субурбії від центрального міста» (Mezentsev et al., 2019, p. 16). В контексті соціальної диференціації мешканців («старожили- новосели», «мешканці старої (історичної) забудови - мешканці нової забудови», «мешканці садибної забудови - мешканці багатоповерхової забудови») науковці визначили траєкторій розвитку приміських просторів Києва та Вінниці: приміські простори посилюють внутрішне різноманіття, мозаїчність, характеризуються гетерохронністю розвитку окремих своїх просторових та функціональних складників (Mezentsev et al., 2020, p. 73). Гіпотетично можна припустити, що деякі тенденції простежуються в межах садибної забудови великих міст.

Об'єктом дослідження обрано мікрорайон садибної забудови Козельники, що було приміським селом південніше Львова до 1959 року. Територія села зазнала суттєвих трансформацій у зв'язку 3 просторовим розповзанням Львова. Зараз Козельники фактично є буфером між південною промисловою зоною та новим житловим мікрорайоном Сихів. Відстань по прямій лінії від площі Ринок до колишньої будівлі сільської ради становить приблизно 4,8 км, а по міських шляхах - 6 км. При цьому максимальний радіус від центру Львова до адміністративної межі міста на вул. Городоцькій сягає приблизно 9 км.

Мета дослідження полягала у виявленні просторових аспектів функціонування та напрямів трансформації зони садибної забудови у місті Львові на прикладі мікрорайону Козельники, оцінці проблем територіального розвитку садибної забудови загалом та колишнього приміського села Козельники зокрема, наданні рекомендацій для прийняття оптимальних містопланувальних рішень.

Методика досліджень. Вивчення трансформаційних процесів локального міського простору потребує застосування спеціальних методів. Інформаційною базою дослідження населення мікрорайону Козельники були матеріали Геопорталу відкритих даних Львівської міської ради, зокрема кількість населення по окремих домогосподарствах (адресах) за 2017 р., у тім числі по вікових групах та статі (Geoportal of open data ... 2020). Однак, порівняння офіційної статистики 3 реальними даними стосовно наявного населення по десяти домогосподарствах виявило деякі незбігання показників у шести випадках (офіційна статистика містить інформацію про зареєстрованих осіб, а не фактично проживаючих). Це засвідчує необхідність використання у суспільно-географічних дослідженнях локальних об'єктів даних переписів, а не поточного обліку.

Для оцінки сучасної планувальної структури мікрорайону Козельники проаналізовано дані земельного кадастру станом на 2020 рік, Генеральний план міста Львова на період 2011-2025 років, дані картографічних сервісів Google Maps та Google Earth. Картографічною основою для виявлення трансформаційних процесів у геопросторовій організації садибної забудови були карти Львова та передмість з кінця ХІХ ст.

3 метою отримання додаткової інформації про геопросторові особливості функціонування і трансформації садибної забудови мікрорайону Козельники було застосовано метод спостереження упродовж 1991-2021 років, у тім числі метод включеного спостереження у період 2008-2021 років. У 1991, 2009, 2019 та 2020 роках у різні сезони було проведено обходи території з метою виявлення особливих рис землекористування, оцінки головних проблем розвитку мікрорайону. Додатковими матеріалами для аналізу більш тривалого періоду розвитку території стали результати декількаразового усного опитування чотирьох мешканців Козельник у віці понад 76 років, які проживають тут 3 кінця 1940-х років.

Для виявлення окремих рис повсякденного життя людей i сучасних проблем розвитку зони садибної забудови застосовано метод опитування. Анкета в Google Forms містила сім запитань і пропонувалася для жителів мікрорайону у групі Козельники/Кольонія Group на сторінці Козельники. Інфо у Facebook. Упродовж 28.10.2020-12.11.2020 pp. участь в анкетуванні взяло 63 особи, що становить понад 14 \% від загальної кількості учасників групи. Серед опитаних - особи у віці понад 30 років $82,5 \%$, у тім числі 22,2 \% у віці 60 років і старше. Статистичне опрацювання отриманих результатів анкетування здійснено 3 використанням програми Microsoft Excel.

Виклад основного матеріалу. У сучасній геоурбаністиці немає одностайності у застосуванні терміну для позначення явища розташованих поруч односімейних приватних будинків разом iз земельною ділянкою та іншими спорудами у i межах. У генеральних планах міст, які базуються на державних будівельних нормах, у сельбищній зоні виділяють 3-поміж інших зону садибної житлової забудови. Цей термін у наукових публікаціях $є$ 
найбільш уживаним, однак часто слово «житлової» автори цілком справедливо упускають, адже садибна забудова логічно не може бути нежитловою. У працях вітчизняних науковців натрапляємо й на інші синонімічні терміни - приватні односімейні будинки, приватні садиби, низькоповерхова приватна забудова (Mezentsev et al., 2019), індивідуальна житлова забудова (Jakubowski, 2007), малоповерхова однородинна забудова 3 присадибними ділянками (Sadowska, 2015).

В англомовній геоурбаністиці надають перевагу терміну single-family residential zone (зона односімейного житла), а також окремо виділяють suburban homesteads (приміські садиби). У китайській геоурбаністиці, у зв'язку з трактуванням самого існування явища сільської забудови як міської проблеми, у середині 1990-х років з'явився термін «село в місті»: це село, яке оточене міською забудовою, концентрує в собі низку негативних рис, що в метафоричному означенні є «злоякісною пухлиною» в організмі міста (Smith, 2014).

За генезисом виділяємо три типи садибної забудови у великих містах.

1. Колишні приміські села, які у результаті просторового розповзання міста адміністративно увійшли до його складу. У Львові - це, наприклад, Козельники, Кривчиці, Лисиничі, Збойська. В цій підгрупі можна виділяти окремі підгрупи за тривалістю перебування у межах великого міста. Більшість таких сіл зазнали суттєвих просторових трансформацій та надбали цілий комплекс проблем, обумовлених тим, що розвиток соціальної сфери, транспортної та інженерної інфраструктури міста Львова у другій половині XX ст. не враховував демографічні та просторові аспекти їхнього розвитку. Та й загалом такі території у великих містах розглядалися лише як ділянки для перспективного будівництва нових житлових мікрорайонів та промислових підприємств.

2. Спеціально спланована зона садибної забудови у кінці XIX - першій половині XX ст. на межі тогочасного Львова. Такі «новобудови» призначались для різних соціальних категорій населення, отже i тепер володіють відмінними рисами, що дозволяе виділити окремі підтипи:

2.1. Садибна забудова, яка планувалася для заможних сімей та комплексно зводилася за якісними архітектурними проектами, що базувалися на ідеях міста-саду: садиби були достатньо великими за площею, відзначалися покращеними планувальними рисами, поряд 3 будинком був сад та широка репрезентативна фасадна лінія. У Львові це Кастелівка, Софіївка тощо (Jakubowski \& Jakubowski, 2017). Це територія, яка найменше зазнала просторових трансформацій, однак в останнє десятиліття починає ущільнюватися завдяки точковому вкрапленню середньо- i багатоповерхових будівель. Сьогодні їі перевагами $\epsilon$ : розташування у середмісті, добре організована транспортна інфраструктура, наявність інженерних мереж та вдало озеленених ділянок, естетично привабливі архітектурні форми;
2.2. Садибна забудова, яка планувалася для наукової, інтелектуальної еліти міста (Професорська колонія), для державних службовців Львова («Власна Стріха», тепер вул. П. Мирного) або військової еліти (Офіцерська колонія в районі Штіллерівки, тепер вулиці Черешнева, В. Самійленка, О. Пчілки). Вона має багато спільних ознак 3 попереднім підтипом, але вирізняється дещо меншими присадибними ділянками, а частина будинків спарені. Можливості нового будівництва тут обмежені. Ущільнення забудови відбувається шляхом добудови одноосібного житла углиб садиби, або зведенням середньо- і багатоповерхових будинків на маленьких ділянках упритул до дороги з мінімальною площею прибудинкової території та відсутністю місць для паркування автомобілів;

2.3. Спеціально виділені території для робітничих поселень поблизу промислових і транспортних зон великих міст (робітничі колонії, наприклад, Сигнівка у Львові). Це ареали садибної забудови із невеликими площами присадибних ділянок, відсутністю землі для сільськогосподарської діяльності, надзвичайно щільним розміщенням будівель, дуже вузькими вуличками, мінімальними, часто цілком вичерпаними можливостями для розширення житла по горизонталі. Нині тут можна спостерігати процеси розростання садибної житлової забудови вгору. Незначна кількість зелених насаджень робить садибну забудову цього підтипу естетично малопривабливою. Однак, саме орієнтація таких колишніх поселень на зв'язки 3 індустріальним сектором міста сьогодні обумовила добру транспортну пов'язаність з іншими районами міста.

3. Невеликі за площею ареали садибної забудови на ділянках з чималим перепадом висот, вкраплені у межах старої забудови центральної частини міста (вулиці Драгоманова, Глібова, Кирила і Мефодія тощо).

Процеси урбанізації, збільшення людності міст у межах окремих територій/ареалів історико-географічних одиниць держави завжди супроводжувалося територіальним розростанням міської забудови за окремими моделями і схемами, що зумовлювалося загальноісторичними особливостями розвитку та локальними природними чинниками - орографічною основою i гідрологічною мережею. Просторове зростання Львова з широкої улоговини долини р. Полтви визначалося географічним простяганням у межах Головного європейського вододілу пасм та денудаційних останців 3 перепадами висот до 25-40 м. Олена Степанів вдало обгрунтувала тезу, що «положення княжого міста тісно в'яжеться 3 фізіографією» (Stepaniv, 1992, p. 7). Розвиток передмість відбувався несинхронно. «Найслабше розвивалися передмістя в напрямі джерел Пасіки, Залізної води та лівого берега Полтви» (Stepaniv, 1992, р. 12), тобто на південний захід, захід та схід. Розростання Львова у напрямку села Козельники розпочалося у 1574 р. з будівництва костелу Святої Софії, який знаходився достатньо далеко від міста, на верхній частині сучасної вул. І. Франка. 
Село Козельники уперше згадується в документах 1374 р. Воно розташоване на південь від Львова у верхів'ях річки Зубри. Ї̈ї витоком є одне 3 багатьох джерел, розташоване у східній частині села.

Як свідчать карти початку XX ст. Козельники мали вулично-ланцюгову планувальну структуру: головна вулиця простягалася у широтному напрямку вздовж двох потоків Зубри. Північний ланцюг забудови - це більша частина садиб, які були розташовані на південному схилі Головного Європейського вододілу, відзначалися сприятливою південною експозицією та слабким похилом поверхні. Південний ланцюг житлової забудови 3 меншою кількістю садиб простягався паралельно до північного, мав недостатньо сприятливе мікроположення - більш крутий північний схил до русла $з$ гіршими мікроагрокліматичними умовами. Уздовж сучасної вул. Зелена у меридіональному напрямку простягався третій ланцюг садиб. Від головних вулиць розгалужувалося по декілька бічних вулиць. На північно-східній околиці розташовувалося урочище Дубина: землі належали монастирю ордену Францисканців, а також дисперсно було розміщено декілька садиб. Поряд шляху Львів-Бібрка працювала цегельня, яка використовувала місцеву сировину.

У 1880 р. в гміні Козельники проживало 425 осіб, майже усі римо-католики. Своєї парафії не існувало, сусідніми були римо-католицька парафія в с. Зубра та греко-католицька в с. Сихів (Kozielniki. Geographical dictionary of the Kingdom of Poland... 1880-1914). Приміське розташування позитивно впливало на розвиток села: за даними польського перепису 1921 р. населення зросло до 841 особи, з яких $774-$ римо-католики, 30 - греко-католики та 37 євреїв. А в
1925 р. налічувалося майже 1 тис. жителів. Друга світова війна кардинально змінила етнічний склад населення Козельник. Поляки покинули село, а їхні садиби зайняли українці, які були насильно виселені з українських етнічних земель, що опинилися у складі Польщі. Нащадки переселенців сьогодні становлять переважну більшість населення Козельник, а старше покоління $є$ активними учасниками Об'єднання товариств депортованих українців «Закерзоння».

Варто зазначити, що поява неавтохтонного населення призвела до втрати давніх топонімів на території села. Сучасні окремі антропотопоніми пов'язані з прізвищами людей, родин, чия садиба тепер розташована поряд з географічним об'єктом. Але найчастіше місцевість називають тим топонімом, що співзвучний 3 назвою нових промислових підприємств чи інших об'єктів («коло колії», «хімзавод», «металбаза»). Інколи загальні лексеми набувають значення топоніма (Загумінки).

У XX ст. село Козельники належало до різних адміністративно-територіальних утворень: 31920 р. до 1939 р. - гміна у складі Львівського повіту Львівського воєводства, 1940-1959 рр. село входило до складу Винниківського району Львівської області, а в часи німецької окупації з 1942 р. до 1944 р., разом з 21 іншою громадою у передмісті, було включено в межі Львова як третя адміністративна дільниця Гірське джерело (Shabliy, 2012, p. 163). Приєднання Козельник до Львова відбулося 1959 р. спочатку у складі Галицького, а з 2001 р. - Сихівського району.

У просторовій трансформації села Козельники виокремлюємо чотири ключові етапи:

1. 1866 р. - споруджено залізницю Львів-ІваноФранківськ, яка розсікла село на дві частини, залишивши більшість сільськогосподарських угідь на півночі відрізаними від основної житлової забудови.

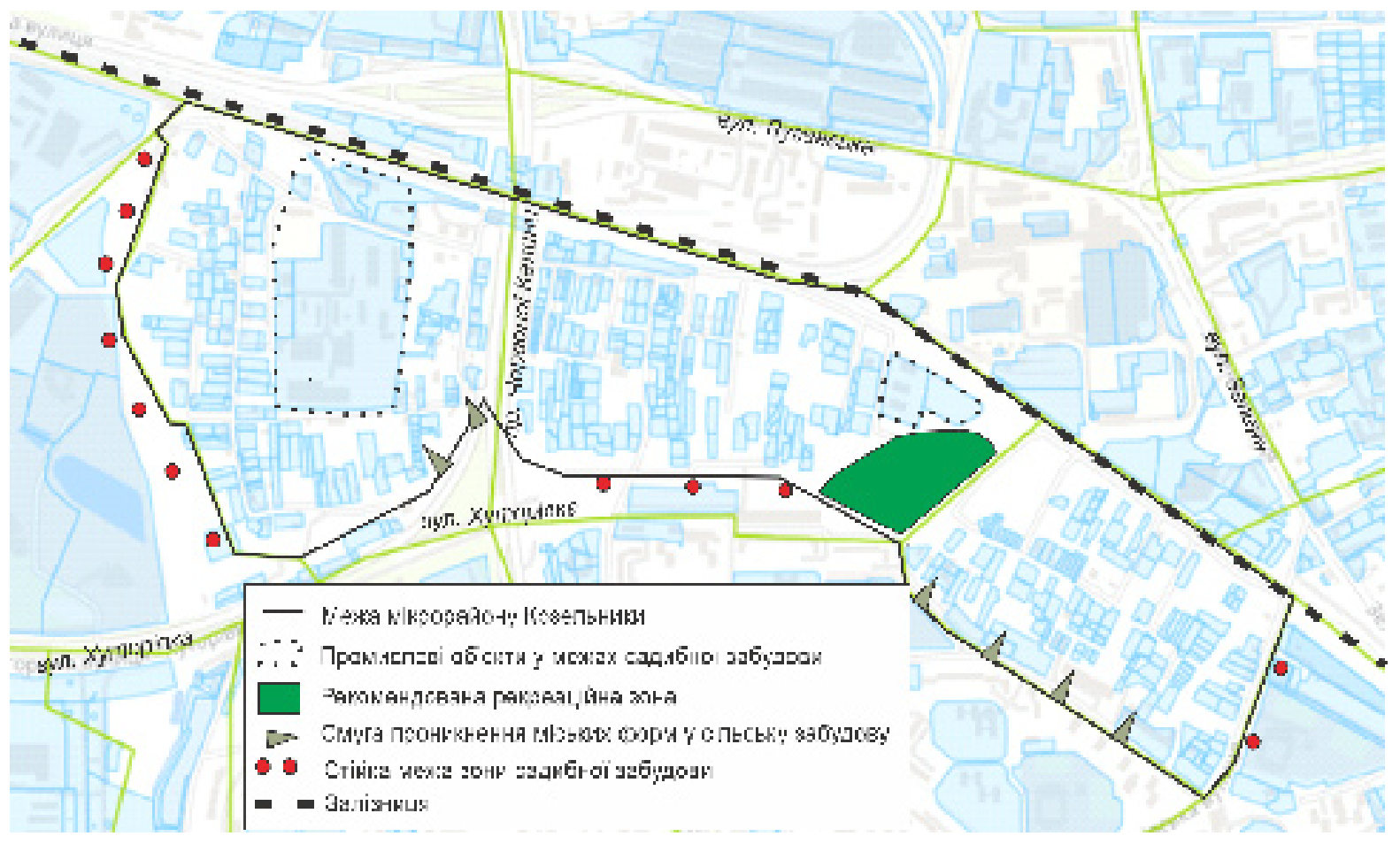

Рис. 1. Зона садибної забудови Козельники. Побудовано на основі (Landcadastre. Lviv, 2021) 
2. 1950-60 pp. - індустріалізація та розповзання Львова у повоєнний період визначили сучасну просторову конфігурацію території Козельник. Більша за площею північна та східна частина села увійшла до складу південної промислової зони Львова. Тут на вільних землях або на місці знесених садиб побудували заводи фрезерних верстатів (територія монастиря), Полярон, Електропобутприлад, меблеву фабрику, домобудівний комбінат, декілька великих складських комплексів. У західній частині житлової забудови села почав працювати хімічний завод 3 виробництва кисню.

3. Початок 1980-х pp. - для зведення багатоповерхівок нового мікрорайону Сихів був знесений південний ланцюг приватних садиб у Козельниках.

4. 2004 р. - завершення процесу реконфігурації сільської території. Проклали новий сихівський шляхопровід на місці сільської вулиці, уздовж якої зруйнували майже усю садибну житлову забудову. Залишки цієї частини села сьогодні збереглися у вигляді окремих реконструйованих садиб поблизу мосту над залізницею.

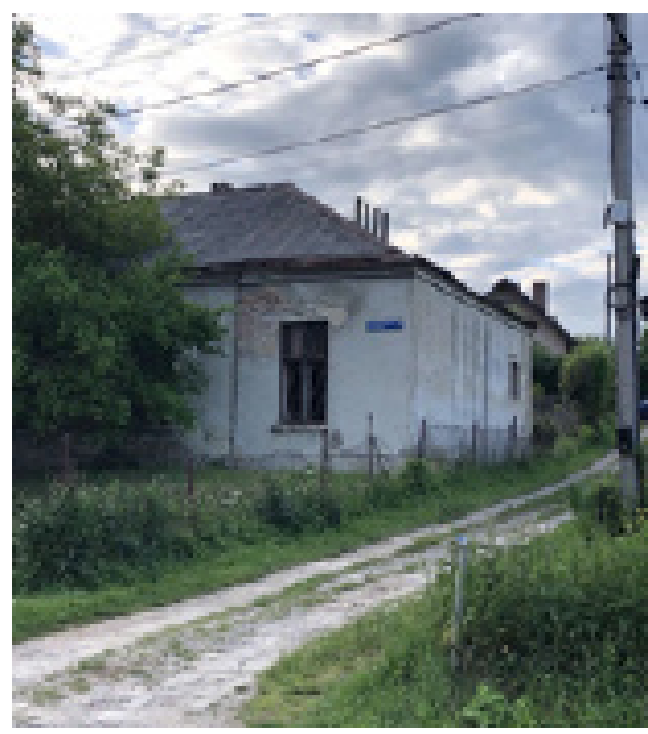

Рис. 2.

Занедбана будівля сільської ради та клубу (фото Гудзеляк І.,

2021)
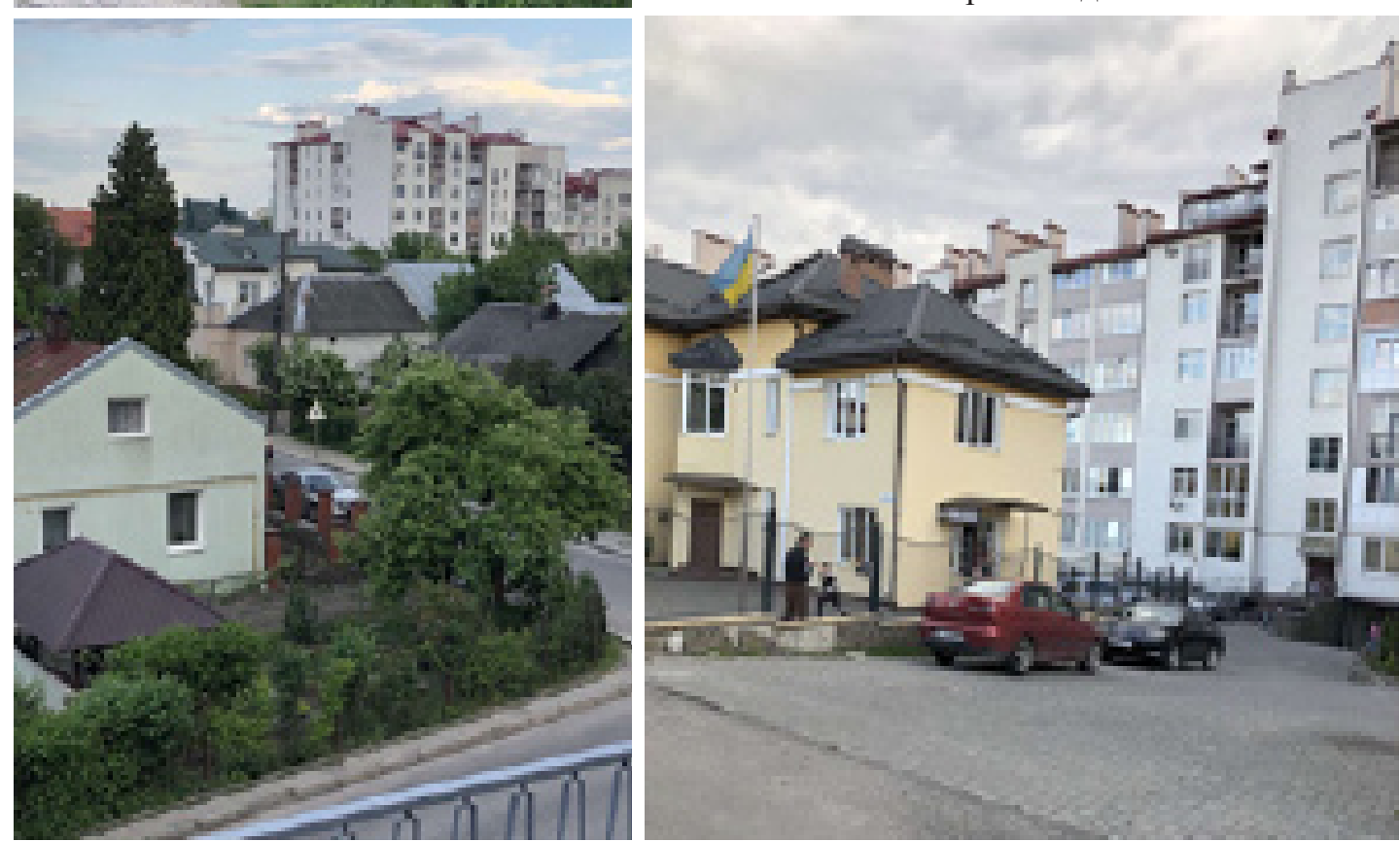

Таким чином, сучасна територія мікрорайону Козельники - це витягнута зона садибної житлової забудови південніше залізниці Львів-Івано-Франківськ. Межує на заході з територіями Львівської духовної семінарії Святого Духа та Українського Католицького Університету, на сході межею $є$ вулиця Зубрівська, на півдні - вулиці Хуторівка та Манастирського. Загальна протяжність садибної забудови з північного заходу на південний схід - 2 км, 3 півночі на південь - максимально 630 м (рис. 1).

У результаті значних трансформаційних процесів колишнє село сьогодні - це три відносно автономні ареали. В західній частині поряд 3 садибною житловою забудовою функціонуе хімічний завод, розташовано п'ять малоповерхових багатоквартирних будинків, які призначалися для робітників, будівля колишнього дитячого садочка. Центральна частина відділена від східної (Кольонії) територією бази кольорових металів та відстійниками технічної води 3 колишнього домобудівного комбінату. Це - житлова зона, включаючи занедбану будівлю сільської ради та клубу (рис. 2). На окремих ділянках зведено середньоповерхові будинки, які розташовані у тісному оточенні садиб (рис. 3). У майбутньому існує ймовірність ще більшого розчленування території садибної зони Козельник: ізоляція східної частини, Кольонії, у разі будівництва продовження вулиці Хуторівка, яка згідно Генерального плану має поєднати сихівський міст і вул. Зелену (General development plan of Lviv ..., 2008).

Серед колишніх сільських споруд, які опинилися в оточенні багатоповерхової забудови Сихова, збереглася лише козельницька восьмирічна школа, яка після капітального ремонту виконуе функції Центру дитячої та юнацької творчості МЖК-1 Сихівського району.

Попри те, що Козельники мають чіткі межі, які є стійким бар'єром між сільською і міською забудовою, цю територію не можна вважати житловим островом: на окремих ділянках 3 найтіснішим сусідством 3

Рис. 3. Поєднання міських і сільських форм у Козельниках (фото Гудзеляк I., 2021) 
багатоповерхівками Сихова нова висотна забудова проникає у садибну зону та розмиває фізичні межі між містом і селом. Нині такі процеси найбільш активні в південно-східній частині уздовж вул. Манастирського (див. рис. 1).

Транспортні виходи з Козельник мають південну орієнтацію, а також безпосередньо на сихівський міст. Однак, проблемою для мешканців є велика часова доступність до зупинок громадського транспорту, особливо з району хімзаводу.

Внутрішня планувальна структура тих ділянок колишнього села, які збереглися дотепер, $є$ чи не найбільшим гальмом подальших внутрішніх трансформацій простору. Більшість домогосподарств володіють достатньо великими присадибними ділянками (Landcadastre. Lviv, 2021). Однак, сформована планувальна структура самих садиб загалом не сприятиме їхньому майбутньому поділу між різними власниками, адже фасадна ширина більшості 3 них $є$ вузькою при мінімальній площі фронтальної, репрезентативної зони. Тому, через неможливість влаштувати додаткові в’їзи, продаж землі іншим власникам у більшості випадків не здійснюється, а розширення забудови можливе лише углиб за рахунок використання городу чи саду. Вузькі вулиці в основному розраховані на проїзд одного автомобіля, а приватизовані земельні ділянки у подальшому гальмуватимуть включення у сільський культурний ландшафт міських багатоквартирних будівель. Максимальна місткість окремих перспективних ділянок на околицях мікрорайону - дво- або триповерхові спарені котеджі на декілька сімей при умові доступності інженерних мереж. Саме такі особливості у подальшому визначатимуть переважно садибний, дещо ущільнений, проте без подрібнення земельних ділянок, тип забудови мікрорайону. А якщо врахувати результати опитування жителів (87,4\% ствердно відповіли, що не планують змінювати свого місця проживання, також $85,7 \%$ негативно ставляться до зведення багатоповерхівок у межах садибної забудови Козельник), то на найближчу перспективу просторові форми та планувальна структура території Козельник залишатимуться практично незмінними.
Дослідження трансформаційних процесів у районах садибної забудови також має враховувати питання демографічного розвитку та соціальних змін. За даними геопорталу відкритих даних Львівської міської ради визначено, що загальна кількість населення садибної забудови Козельник у 2017 р. становила 1163 особи. Також по окремих територіальних частинах розраховано загальну людність, частку молодого населення, визначено рівень демографічного старіння (табл. 1).

Оскільки частка дітей в Козельниках (18,5 \%) збігається 3 аналогічним середнім показником у Львові (18,6 \%), можна припустити, що для населення колишнього села, як і загалом міському населенню, властива нова модель репродуктивної поведінки, яка відзначається установками на формування малодітних сімей. Однак, за головними рисами матримоніальної поведінки населення Козельник більшою мірою тотожне 3 сільським: середній розмір домогосподарства становить 4,7 особи, тоді як у Львівській області - 3,01 особи, а в Україні 2,58 особи (Social and Demographic Characteristics ..., 2019, p. 9). Зрештою, саме наявність власного житла та можливість його розширення сприяє домінуванню складних сімей. Рівень демографічного старіння в Козельниках є дещо вищим (24,2 \%), ніж у Львові (22,3\%).

За багаторічними спостереженнями (при відсутності офіційної статистики) можна стверджувати, що інтенсивні міграційні потоки відсутні. За результатами анкетування, 54 \% респондентів вказали, що їхня сім'я проживає у Козельниках понад 70 років, ще $32 \%$ - понад 50 років. Отже, у соціальному аспекті Козельники - це залишкове сільське утворення, яке соціально трансформувалося головно через зміну поколінь та набуття нових соціальних статусів мешканцями. Загалом, таких соціальних рис, які властиві будьякому сільському населенню, не збереглося: тривалий доступ до вищої освіти у м. Львові призвів до формування «міської» зайнятості у двох-трьох поколіннях.

Внаслідок впливу певних чинників простежуємо низький рівень соціальної інтеграції

Таблиця 1

Населення мікрорайону Козельники, 2017 р.

Складено автором за даними (Geoportal of open data ..., 2020)

\begin{tabular}{|l|c|c|c|c|c|c|c|}
\hline $\begin{array}{c}\text { Територіальні } \\
\text { частини } \\
\text { садибної } \\
\text { забудови }\end{array}$ & $\begin{array}{c}\text { Кількість } \\
\text { нслення, }\end{array}$ & $\begin{array}{c}\text { Частка } \\
\text { населення } \\
\text { у віці 0-17 } \\
\text { років, \% }\end{array}$ & $\begin{array}{c}\text { Частка } \\
\text { населення } \\
\text { у віці } 60 \\
\text { років і } \\
\text { старше, } \%\end{array}$ & $\begin{array}{c}\text { Кількість } \\
\text { домогоспо- } \\
\text { дарств, од }\end{array}$ & $\begin{array}{c}\text { Середній } \\
\text { розмір } \\
\text { домогоспо- } \\
\text { дарства, } \\
\text { осіб }\end{array}$ & $\begin{array}{c}\text { Питома вага } \\
\text { домогоспо- } \\
\text { дарств у } \\
\text { загальній } \\
\text { кількості, \% }\end{array}$ & $\begin{array}{c}\text { Питома вага } \\
\text { населення } \\
\text { загальній } \\
\text { кількості, \% }\end{array}$ \\
\hline $\begin{array}{l}\text { Район } \\
\text { хімзаводу }\end{array}$ & 345 & 20,3 & 24,9 & 92 & 3,75 & 37 & 30 \\
\hline Центр & 467 & 17,3 & 21,0 & 92 & 5,1 & 37 & 40 \\
\hline Кольонія & 351 & 18,2 & 27,1 & 65 & 5,4 & 26 & 30 \\
\hline Всього & 1163 & 18,5 & 24,2 & 249 & 4,7 & 100 & 100 \\
\hline
\end{tabular}


у межах мікрорайону. По-перше, існує поділ на підставі приналежності населення Козельник до п’яти церковних парафій. По-друге, просторова трансформація мікрорайону та фізичний поділ території на три відносно ізольовані частини, змінила орієнтацію сімей 3 дітьми на різні дошкільні й загальноосвітні заклади сусідніх мікрорайонів - Сихова та Нового Львова. Потретє, відсутній громадський центр в мікрорайоні: колишній сільський клуб, який об'єднував молодь, недіючий. Також уже немає гуртків і футбольної команди. Попри існуючі родинні або дружні (наприклад, між колишніми однокласниками) зв'язки, жива комунікація між людьми слабшає, а створення групи Козельники/Кольонія у Facebook $\epsilon$ свідченням не лише віртуалізації міжлюдських взаємин, а й утвердження стійких урбанізованих рис повсякденної поведінки.

Однак, опитування жителів мікрорайону дозволило виявити окремі гібридні прояви повсякденного життя людей. Передусім це стосується способу використання присадибних ділянок переважно для вирощування овочів та садівництва (рис. 4.А). Понад 50\% опитаних в основному забезпечують свої родини особисто вирощеними сезонними овочами i фруктами, лише $6,3 \%$ взагалі нічого не вирощують (рис. 4.Б). В окремих домогосподарствах розводять домашню птицю, а ще донедавна - корів та кіз. Візуальне обстеження території також дозволило зробити висновок про менші площі (у порівнянні з деякими приміськими селами у Львівській агломерації) рекреаційних зон у межах садиб, а також дешевші і простіші атрибути ландшафтного дизайну прибудинкової території, чи навіть його відсутність.
Ознакою сільського способу життя є повсюдна практика «приватизації» громадського простору, що виявляється в догляді за дорогою (очищення від снігу, засипання вибоїн на грунтових дорогах, які у мікрорайоні переважають), висаджування квітів чи декоративних кущів уздовж дороги, прибирання поблизу власних садиб (рис. 5). Однак, така діяльність - це і вияв громадського обов'язку мешканців, що загалом притаманно сільським жителям, i необхідність в умовах відсутності комунальних послуг централізованого характеру. Сільською практикою, що властива більшості домогосподарствам, $є$ облаштування «прозорих» парканів. У новозведених садибах на куплених земельних ділянках нові власники як правило зводять високу «глуху» огорожу з надійним захистом.

Суттєвими проблемами, на які вказали мешканці мікрорайону Козельники під час анкетування (пропонувалось вибрати декілька варіантів), були: неякісні дороги $(85,7 \%)$, відсутність централізованого водопостачання та каналізації (39,7\%), відсутність закладів торгівлі $(38,1 \%)$, відсутність вуличного освітлення (36,5\%), погана екологія (очевидно, внаслідок безпосередньої близькості до залізниці) та складність доїзду сервісних служб (по 25,4\%), висока злочинність (17,5\%). Попри існування багатьох проблем у зоні садибної забудови, лише 12,6\% опитаних бажають змінити місце проживання для покращення побутовихумов іуникнення необхідності доглядати за садибою. Також $33,3 \%$ респондентів вказали на «байдужість мешканців до свого району», що опосередковано підтверджує процес соціальної ізоляції людей в межах окремих садиб.

Загалом перелічені проблеми властиві й іншим районам садибної забудови першого типу, які

\title{
А. Як Ви використовуете свою земельну ділянку?
}

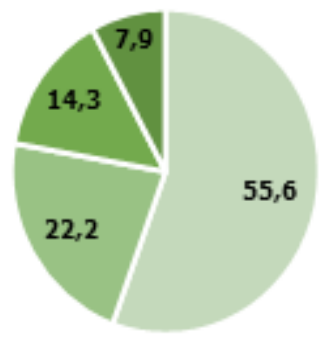

" невелика зона відлочинку, решта город і сад

" тільки як городі сад

" невеликий город, решта відпочинкова зона

- тільки для відпочинку

Б. Наскільки Ви забезпечуете се6е сезонними овочами і фруктами з власного городу?

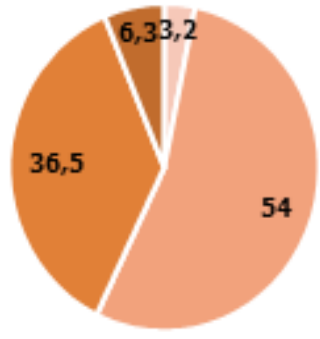

\author{
повністю се6е забезпечую \\ " достатньо, але дещо тре6а купувати \\ - мало, майже все купую \\ - зовсім нічого не вирощую
}

Рис. 4. Використання земельних ділянок домогосподарствами в Козельниках (за даними соціологічного опитування), \% 
на сучасному етапі розвиваються переважно за схемою «знизу вгору» (Ibrahim et al., 2017), тобто модернізуючи, трансформуючи середовище лише за рахунок особистих коштів, без фінансових ресурсів міста чи держави. Дотепер трансформація простору зони садибної забудови Львова враховувала лише інтереси мешканців суміжних мікрорайонів багатоповерхового житла. Очевидно, що для вирішення зазначених проблем міській владі необхідно передусім усвідомити цінність зон садибної забудови як просторів, що володіють багатьма перевагами (озеленена зона з можливостями фізичної ізоляції сімей, що особливо важливо у часи пандеміі), виділяти кошти на створення інженерної інфраструктури, що $\epsilon$ елементарним атрибутом цивілізованих умов проживання людей. Планування соціальної сфери окремих районів міста має здійснюватися 3 урахуванням геопросторової організації зон садибної забудови, транспортної пов'язаності і пішохідної доступності до освітніх, медичних та торговельних закладів. Будівництво багатоповерхового житла допустиме лише при умові дотримання усіх будівельних норм та врахування наявності доріг, їхньої пропускної здатності та можливості облаштування дорожньої інфраструктури.

Для забезпечення сталого розвитку міст сучасні практичні рішення в геоурбаністиці повинні бути природоорієнтовані. Саме зони садибної забудови дозволяють 3 найменшими капіталовкладеннями досягнути бажаного ефекту. Так, у мікрорайоні

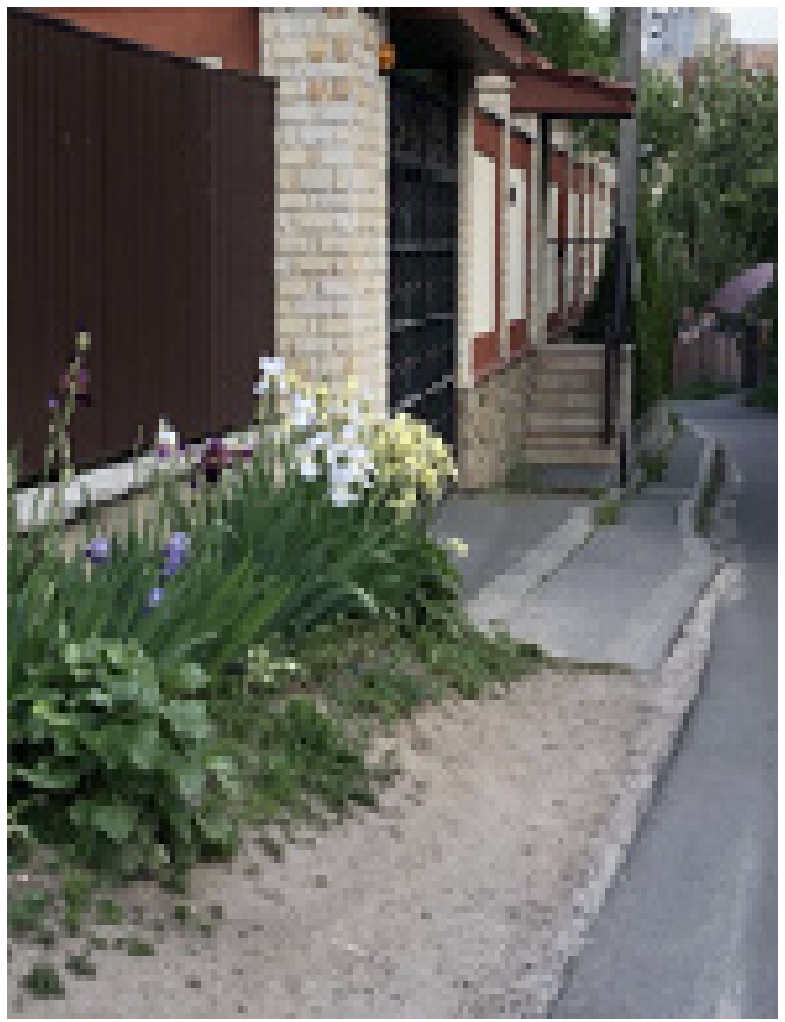

Рис. 5. Приклад доместикації вулиці (фото Гудзеляк І., 2021)
Козельники розташовано відстійники технічної води колишнього домобудівного комбінату 3 деревною рослинність навколо них. Враховуючи безпосереднє сусідство багатоповерхівок та відсутність поруч громадських і відпочинкових зон, цей занедбаний простір варто перетворити на рекреаційну зону (рис. 6).

Висновки. Просторове різноманіття у містах, наявність неоднотипних архітектурних та планувальних форм житлової забудови створює привабливість міста для різних категорій населення. За генезизом виділено три типи садибної забудови у великих містах. У Львові найбільш гострими проблемами територіального розвитку відзначаються колишні сільські поселення, які були приєднані до міста у другій половині XX ст.

Трансформація зони садибної забудови мікрорайону Козельники обумовлена будівництвом залізничної мережі, індустріальним розвитком південних околиць Львова та зведенням нового багатоповерхового житлового мікрорайону Сихів. У результаті втрачено частину сільської забудови, сформовано внутрішні бар'єри між колись єдиним розселенським утворенням, а сучасна планувальна структура не пристосована до функціонування у сусідстві 3 міськими формами та не забезпечує соціальні потреби населення. Гострою проблемою $€$ застаріла інженерна інфраструктура (у багатьох садибах відсутнє централізоване водопостачання i водовідведення), неякісні (переважно грунтові) дороги.

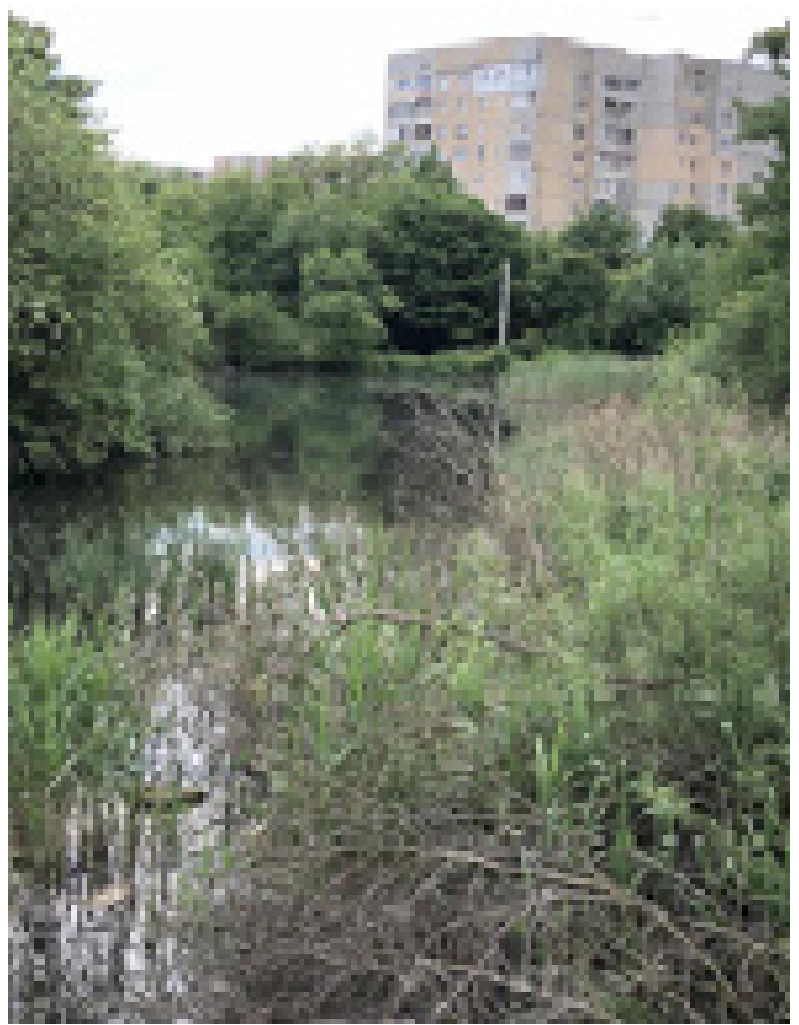

Рис. 6. Територія навколо колишніх технічних водойм, яка потребує ревіталізації (фото Гудзеляк І., 2021) 
Водночас міські архітектурні форми поступово проникають у зону садибної забудови мікрорайону Козельники, особливо у південно-східних околицях. Проте найбільш інтенсивно відбувається ущільнення забудови за рахунок зведення прибудов, або нового односімейного житла у межах земельних ділянок окремих домогосподарств без їхнього подрібнення. Таким чином формується гомогенний простір, як в матеріальному, так і в соціальному аспекті.

У майбутньому, враховуючи слабкі міграційні мотиви, негативне ставлення мешканців Козельник до багатоповерхового житла, нові суспільні цінності у пандемічному світі та усвідомлені переваги ізольованого життя в окремому будинку з присадибною ділянкою, зона садибної забудови Козельники не зазнаватиме кардинальних трансформаційних процесів. Для створення комфортного середовища, подолання інфраструктурних та соціальних проблем мікрорайону необхідні капіталовкладення у будівництво доріг з твердим покриттям, прокладання інженерних мереж, продовження робіт з освітлення вулиць, організацію комунального обслуговування території, створення рекреаційної зони навколо двох штучних водойм, яка у майбутньому може частково виконувати роль громадського центру для мешканців Козельник. Важливо сприяти малому бізнесу в сфері торгівлі та інших видів діяльності 3 обслуговування населення.

\section{References:}

Adelfio, M. (2014). The future of single-family detached housing. Journal of Urbanism, 7(3), 217-220. Doi: 10.1080/17549175.2014.923638.

General development plan of Lviv until 2025 (2008). [In Ukrainian]. [Генеральний план розвитку м. Львова до 2025

p.]. Retrieved from: www.cityadm.lviv.ua

Geoportal of open data of Lviv City Council (2020). [In Ukrainian]. [Геопортал відкритих даних Львівської міської ради]. Retrieved from: https://map.city-adm.lviv.ua/map/demography\#map

Ibrahim, M.-B., Zulu, L.-C., Bein, F. L. (2017). Settlement in transition: a transformation of a village into a small town in Western Sudan. Urban Forum, 29(3), 85-106. Doi: 10.1007/s12132-017-9323-2

Jakubowski, I. V. (2007). On the terminology of individual housing [In Ukrainian]. [Якубовський I. В. До питання термінології індивідуальної житлової забудови]. Retrieved from: http://vlp.com.ua/files/34_0.pdf

Jakubowski, I. V., Jakubowski, V. B. (2017). Features of planning decisions of manor plots in Lviv in the second half of the XIX - early 30s of the XX century. Modern problems of architecture and urban planning, 47, 420-427. [In Ukrainian]. [Якубовський I. В., Якубовський В. Б. Особливості планувальних вирішень садибних ділянок у Львові другої половини XIX - початку 30-тих років XX ст. // Сучасні проблеми архітектури та містобудування. 2017. № 47. С. 420-427.]

Kozielniki. (1880-1914). Geographical dictionary of the Kingdom of Poland and other Slavic countries, T. IV, (p. 548). [InPolish]. [Słownik geograficzny Królestwa Polskiego i innych krajów słowiańskich. Tom IV. S. 548.] Retrieved from: http://dir.icm.edu.pl/pl/Slownik_geograficzny/Tom_IV/548

Landcadastre. Lviv. (2021). [In Ukrainian]. [Земельний кадастр. Львів]. Retrieved from: https://map.cityadm.lviv.ua/map/land-cadastre $\#$ map $=15 / / 49.80344144070641 / / 24.053964614868164 \& \&$ layer $=9635585433681688$ $1,100 / / 6882640856227290-1,100$

Leinberger, C. (2008). The next slum? The Atlantic Monthly. March 2008.

Mezentsev, K., Provotar, N., Gnatiuk, O., Melnychuk, A., Denysenko, O. (2019). Ambiguous suburban spaces: trends and peculiarities of everyday practices change. Ekonomichna ta Sotsialna Geografiya, 82, 4-19. Doi: 10.17721/24137154/2019.82.4-19 [In Ukrainian]. [Мезенцев К., Провотар Н., Гнатюк О., Мельничук А., Денисенко О. Неоднозначні приміські простори: тенденції та особливості зміни повсякденних практик // Економічна та соціальна географія. 2019. Вип. 82. С. 4-19.]

Mezensev, K. V., Provotar, N. I., Gnatiuk, O. M., Melnychuk, A. L., Denysenko, O. O. (2020). Development Trajectories of Suburban Spaces. Scientific Bulletin of Kherson State University. Series «Geographical Sciences», 13, 63-75. Doi: 10.32999/ ksu2413-7391/2020-13-7 [In Ukrainian]. [Мезенцев К. В., Провотар Н. І., Гнатюк О. М., Мельничук А. Л., Денисенко О. О. Траєкторії розвитку приміських просторів // Науковий вісник Херсонського державного університету. Серія «Географічні науки». 2020, № 13. С. 63-75.]

Sadowska, E.-J. (2015). The Officer's Cooperative Colony in Lviv. Journal of Lviv Politechnic University. Series of Architecture, 816, 160-170. [In Ukrainian]. [Садовська Е. Я. Кооперативна офіцерська колонія у Львові // Вісник Національного університету Львівська політехніка. Архітектура. № 816. С. 160-170.]

Shabliy, O. (ed.) (2012). Lviv: complex atlas. Kyiv: Kartographiya. [In Ukrainian]. [Львів: комплексний атлас / за ред. О. Шаблія. К.: ДНВП «Картографія». 2012. 192 с.]

Smith, N.-R. (2014). On the term "Village-in-city". Retrieved from: http://www.urbanismith.com/blog/2014/7/1/whytalking-about-chinese-urban-policy-is-hard

State Statistics Service of Ukraine (2019). Social and Demographic Characteristics of Households of Ukraine in 2019 [In Ukrainian]. [Соціально-демографічні характеристики домогосподарств України у 2019 році / Державна служба статистики України]. Retrieved from: http://www.ukrstat.gov.ua/druk/publicat/kat_u/2019/zb/07/zb_sdhdu2019.pdf

Stepaniv, O. (1992). Modern Lviv. Guide to Lviv. Reprinted since 1943. Stereotypical. Lviv: Fenix Publishing Center. [In Ukrainian]. [Степанів О. Сучасний Львів. Путівник Львова. Перевидання з 1943 р. Стереотипне. Львів: Видавничий центр «Фенікс». 1992. 144 с.]

Ying, P., Mengsi, T. (2018). Analysis on the Problems and Transformation Strategies of the Village-in-City in Guangzhou - Taking Liede Village as an Example. In 4th International Conference on Social Sciences, Modern Management and Economics (pp. 246-249). 